\section{Rapid concentration of proteins and electrolytes from frozen urine by centrifugation}

\author{
B. A. MCERLEAN From the Faculty of Veterinary \\ Medicine, Veterinary College of Ireland, \\ Ballsbridge, Dublin
}

The method outlined by McErlean (1963) for concentrating antibodies in serum was modified. In the original technique it was considered necessary to allow the frozen serum to thaw completely during centrifugation. Further experiments have shown that protein and electrolytes can be removed rapidly from frozen serum or urine by centrifugation, at relatively low speeds with little or no visible evidence of thawing.

Part of the sample $(25 \mathrm{ml}$.) of urine from a nephritic dog was placed in the barrel of a ' $20 \mathrm{ml}$.' plastic syringe

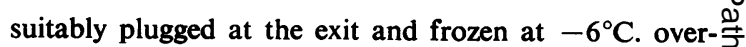
night. A $5 \mathrm{ml}$. glass bottle was placed in the bottom of $\mathrm{a}$ 으 $100 \mathrm{ml}$. centrifuge bucket and the plastic syringe barrel with frozen urine placed on top after removing the $s$ stopper from the exit. Both containers were suitablyo wrapped. The unit was then centrifuged for 1 minute at $\bar{\sigma}$ 3,500 r.p.m. at room temperature, when $3.47 \mathrm{ml}$. of $\overline{\bar{w}}$ yellowish fluid was obtained from the glass bottle and $a \stackrel{\mathbb{D}}{ }$ cylindrical tightly fitting cast of frozen colourless ice was shaken from the syringe barrel.

The fluid concentrate and a sample of the original $\overrightarrow{-}$ urine were analysed for protein by the Biuret method and for sodium using a Beckman spectrophotometer.

The ease with which protein and sodium can be removed from frozen urine or serum is due to the fact? that water freezes first and the substances suspended or: dissolved therein are trapped in the lattice work of ice. crystals in a concentrated form and are removed by $\sigma$ centrifugal force. A critical temperature must obviously be reached when all the constituents are frozen and this technique would not then operate.

TABLE

\begin{tabular}{|c|c|c|c|c|c|c|c|}
\hline & $\begin{array}{l}\text { Quantity } \\
\text { (ml.) }\end{array}$ & $\begin{array}{l}\text { Protein } \\
(m g . \%)\end{array}$ & $\begin{array}{l}\text { Total } \\
\text { Protein } \\
\text { (mg.) }\end{array}$ & $\begin{array}{l}\text { Protein } \\
\text { Recovered } \\
(\%)\end{array}$ & $\begin{array}{l}\text { Sodium } \\
\text { (mEq./l.) }\end{array}$ & $\begin{array}{l}\text { Total } \\
\text { Sodium } \\
(m E q . / l .)\end{array}$ & $\begin{array}{l}\text { Sodium } \\
\text { Recovered } \\
(\%)\end{array}$ \\
\hline $\begin{array}{l}\text { Urine before concentration } \\
\text { Centrifuged concentrate }\end{array}$ & $\begin{array}{l}25 \\
3 \cdot 47\end{array}$ & $\begin{array}{r}280 \\
1,900\end{array}$ & $\begin{array}{l}70 \\
65 \cdot 93\end{array}$ & $\overline{94} \cdot 19$ & $\begin{array}{l}125 \\
850\end{array}$ & $\begin{array}{l}3 \cdot 125 \\
2 \cdot 949\end{array}$ & $\overline{94 \cdot 39}$ \\
\hline
\end{tabular}

REFERENCE

\section{Test for the presence of nitrate not involving carcinogenic reagents}

\section{J. MCLEAN AND A. HENDERSON From the Depart- ment of Chemistry, University of Strathclyde, and the Institute of Obstetrical and Gynaecological Research, Glasgow Royal Maternity Hospital}

Bacteria of the family Enterobacteraceae are distinguished from those of related families by their property of reducing nitrate to nitrite. The presence of nitrite is shown by the production of a diazo dye when an aromatic primary amine is diazotised in the cold and then coupled with a suitable dye-forming substance. Usually the technique followed is that of Griess in which the nitrite is used to diazotise sulphanilic acid in acetic acid whereupon a violet dye is produced on the addition of $\alpha$ naphthylamine or dimethyl- $\alpha$-naphthylamine (Wallace and Neave, 1927). Recently however $\alpha$-naphthylamine has been found to be carcinogenic on renal tract mucosa (Memorandum in Medical Laboratory Technology, 1966). The Griess-Llosvay test detects nitrite when potassium nitrite is present at less than 1 part in 500,000 .

Received for publication 15 June 1966.
As a substitute sulphanilic acid (or aniline) can be used as $\vec{\circ}$ the diazo-forming substance, a pink dye being formed on the addition of $\beta$-naphthol in absolute alcohol; this has an end point of 1 part in 3,200. Conn, Harding, Kligler, Frost, Prucha, and Atkins (1918), however, advocate the use of sulphanilic acid and $\alpha$-naphthol, and it was found응 that the addition of $1 \mathrm{ml}$. of $1 \%$ sulphanilic acid in $5 \mathrm{~N}-$ acetic acid and $1 \mathrm{ml}$. of $1 \% \alpha$-naphthol in absolute alcohol to $8 \mathrm{ml}$. of the nitrite solution allowed the detection of nitrite at a concentration of less than 1 part in 500,000 . The use of $\alpha$-naphthol is convenient as the same reagent is used in a concentration of $5 \%$ for the detection of acetoin (Barritt, 1936).

The use of sulphanilic acid and $\alpha$-naphthol has been checked against eight strains of Escherichia coli, one of $\bar{N}$ Shigella sonnei, two of Salmonella $(S$. typhimurium and $S$ S. emeck), two of Klebsiella pneumoniae, one of Aero- N bacter aerogenes, two of Providencia (type B), two of $N$ Proteus vulgaris, three of Proteus mirabilis, and one of $\omega$ Alkaligenes metalcaligenes.

\section{REFERENCES}

Barritt, M. M. (1936). J. Path. Bact., 42, 441.

Conn, H. J., Harding, H. A., Kligler, I. J., Frost, W. D., Prucha M. J., and Atkins, K. N. (1918). J. Bact., 3, 115.

Wallace, G. I., and Neave, S. L. (1927). Ibid., 14, 377. 